\title{
University Lecturer's Technological Readiness Formation to Use Virtual Educational Environment in Professional Activity
}

\author{
Zaure Orazalina1, Nadezhda Zavalko², Aleksandr Ovcharov³, Yelena Feoktistova4 \\ ${ }^{1}$ D. Serikbayev East-Kazakhstan State Technical University, Ust-Kamenogorsk, The Republic of Kazakhstan \\ ${ }^{2}$ S. Amanzholov East-Kazakhstan State University, Ust-Kamenogorsk, The Republic of Kazakhstan \\ ${ }^{3}$ Altay State Pedagogical University, Barnaul, Russia \\ ${ }^{4}$ Caspian State University of Technologies and Engineering Named after S. Yesenov, Aktau, The Republic of \\ Kazakhstan \\ Email: yelena976@gmail.com
}

Received 6 February 2015; accepted 12 March 2015; published 16 March 2015

Copyright (C) 2015 by authors and Scientific Research Publishing Inc.

This work is licensed under the Creative Commons Attribution International License (CC BY).

http://creativecommons.org/licenses/by/4.0/

(c) (i) Open Access

\section{Abstract}

The paper presents the process of designing a model of university lecturer's technological readiness formation to use virtual educational environment while credit education system. The outcomes of the experimental research during four stages are presented in the paper.

\section{Keywords}

Virtual Educational Environment, Technological Readiness, Credit Education Technology

\section{Introduction}

Orientation for innovative higher education development, implementation of new information-communicative technologies is initiated by the inclusion in the process of Kazakhstan integration with European countries in the area of education. Bologna decisions and credit education technology place special demands for educational process subjects, their activities' encouragement, and learners' independent work. Virtual educational university environment built on the basis of information-communicative technologies becomes an important instrument of their realization, content and technological filling, which is constantly changing. One of the perspective trends is teachers' training modeling for the perception of constant technological and content changes to scientific-pe-

How to cite this paper: Orazalina, Z., Zavalko, N., Ovcharov, A. and Feoktistova, Y. (2015) University Lecturer's Technological Readiness Formation to Use Virtual Educational Environment in Professional Activity. Open Journal of Social Sciences, 3, 128-132. http://dx.doi.org/10.4236/jss.2015.33020 
dagogical comprehension of the processes taking place in the network, which is in advance of education technologies, integrating modern possibilities of information-communicative technologies containing professional activity. The actuality of the problem is strengthened by the fact that every university lecturer should be ready to work in virtual university environment in contrast to traditional models of education and when formed information communication technology becomes supplementary but not determining instrument in educational process realization.

\section{Main Part of the Research}

The goal of the research to design, experimentally approve and implement the model of formation of technological readiness of the university lecturer to the use of virtual educational environment while credit education technology.

Methods of research include theoretical analysis, test experimental work, study and generalization of pedagogical experience, questionnaire, discussion, testing; method of telecommunication projects, methods of mathematic research data processing.

Test experimental work was carried out on the basis of S. Amanzholov East-Kazakhstan state university. 324 professors participated in the research.

Credit technology researches [1] [2] point out the following advantages of it as high degree of academic freedom, systematic step-by-step control of education work, possibility of international credits transfer, independent character of students' educational activity, etc. As for disadvantages of credit technology realization in the Republic of Kazakhstan they include the following: insufficient provision of the students with educational-methodical materials, deficit of course books and educational aids, limitation of access to those available which negatively influence learners' independent work.

Another important problem is students' unpreparedness to independent work, their inability to orient in the information flow and adapt to new conditions of education. Bologna process optional parameters have great significance in educational process planning and organization. Among them are distant learning, electronic courses, module system. The use of IT-technologies optimizes the realization of the parameters mentioned above. Learning in a virtual education environment has a number of psychological-pedagogic problems. According to A.A. Andreyeva and V.I. Soldatkinthe system of higher education places definite demands to it [3] [4]. While credit technology implementation, this list can be enlarged with the following: expanding the provision of telecommunication means for virtual educational environment for independent work, variety of applied programs and systems (including testing systems), providing education quality improvement, provision with multimedia opportunities in electronic educational resources provision.

The central element in educational activity organization in a virtual educational environment is university lecturer readiness for the work in this environment, but existing approaches of university lecturer readiness formation to the work in this environment do not completely correspond to modern conditions.

Virtual educational environment in the present research is understood as information Internet/Intranet environment, integrating electronic educational content, user educational services, applied software and infrastructure of network interaction of educational process subjects, realized on the basis of telecommunication networks. Virtual educational environment should contain the following components: information content, program service and apparatus telecommunication.

Lecturer's technological readiness is necessary for efficient interaction in this environment. It is defined as the ability of the professor to solve professional objectives with the use of means and methods of information communication technologies, i.e. carry out information activity on the collection, processing, delivery and storage of informational resource with the aim of automation of the processes of informational-methodical provision, create, evaluate and realize the opportunities of electronic educational resources and distributed in the Internet information content of educational purpose, organize network interaction (communication) between the subjects of educational process and interactive services, functioning on the basis of information-communication technologies, manage the process of learners' independent work in a virtual educational environment.

The following components in the structure of university lecturer technological readiness are necessary: motivational, cognitive, operational, reflexive, and also the stages of technological readiness formation: applied, network and interactive.

The developed model (Figure 1) was approved and experimentally implemented (during the process of lec- 


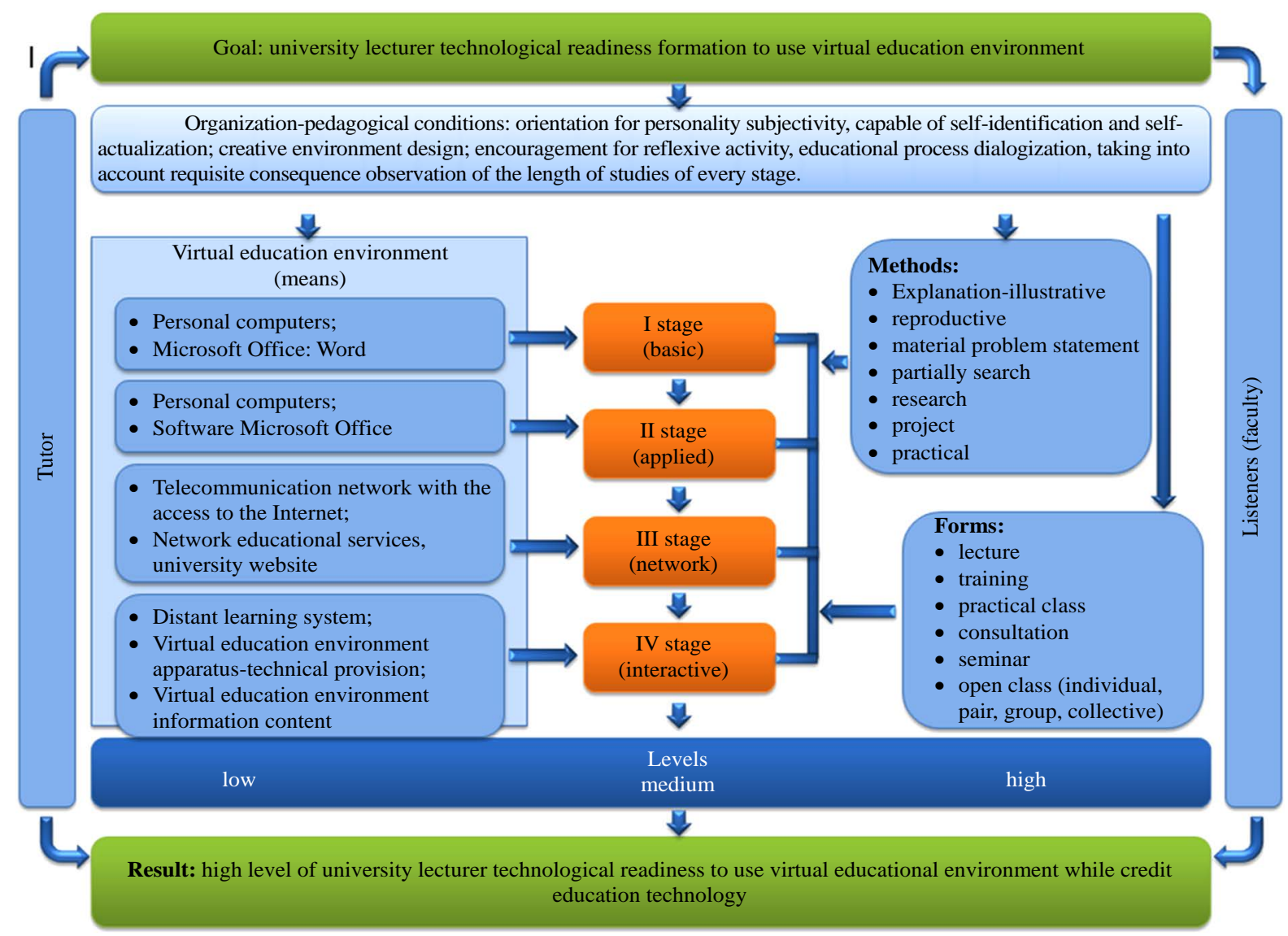

Figure 1. The model of step-by-step formation of university lecturer readiness to use virtual educational environment while credit educational technology.

turers' training for professional activity in the conditions of credit educational technology) in the conditions of S. Amanzholov East-Kazakhstan state university.

The research on the realization of the designed model of university lecturers' technological readiness formation to use virtual educational environment while credit educational technology was carried out in three stages: diagnosis, forming and control. Respondents' selection at the diagnosis stage of experimental work contained 324 people. The basis of experimental research was S. Amanzholov East-Kazakhstan state university.

According to the results of the first stage of technological readiness formation it is necessary to point out that experimental group respondents have shown better results which is the consequence of lecturers' teaching on the special program of the special course under tutors' guidance (Table 1). During the second stage intermediate diagnostic test was held which was in respondents' testing and questionnaire. During the second stage of the experiment due to objective reasons general number of respondents, composing control group was 122 people and experimental group-130 people.

To conclude the second stage of the experiment of the course training intermediate test was held in both groups of the experiment participants. Questionnaire results have shown the level of maturity of motivational component, the result of the testing have shown the level of maturity of the cognitive component, the results of the evaluation of the deigned electronic educational resources have shown the formation of operational component of technological readiness.

According to the results of the testing (cognitive component) and expert evaluation of distant courses in MOODLE system (operational component) the following outcomes were received (Figure 2).

The outcomes show high level of the maturity of cognitive and operational components of technological readiness in the experimental group, that proves the efficiency of the conducted lecturers' course training methods.

To conclude and prove the results of intermediate diagnosis final diagnosis in the form of the questionnaire was carried out. 
Technological readiness formation level was determined on the stages of education (basic, applied, network and interactive) according to the results of the questionnaire.

The results of the final diagnosis are presented in Table 2.

Table 1. University lecturer technological readiness levels characteristics.

\begin{tabular}{|c|c|c|c|}
\hline Levels/Components & Low & Medium & High \\
\hline Motivational & $\begin{array}{l}\text { Absence of the need to use PC, } \\
\text { applied software, network } \\
\text { technologies, interactive } \\
\text { communication to organize } \\
\text { educational process while credit } \\
\text { education technology }\end{array}$ & $\begin{array}{l}\text { Interest to use PC, applied software, } \\
\text { network technologies, interactive } \\
\text { communication to organize } \\
\text { educational process while credit } \\
\text { education technology }\end{array}$ & $\begin{array}{l}\text { The need to use PC, applied software, } \\
\text { network technologies, interactive } \\
\text { communication to organize educational } \\
\text { process while credit education } \\
\text { technology }\end{array}$ \\
\hline Cognitive & $\begin{array}{l}\text { Minimum knowledge about PC, } \\
\text { software, electronic educational } \\
\text { resources, their design and use, } \\
\text { ways of network interaction and } \\
\text { interactive communication in the } \\
\text { framework of educational process } \\
\text { while credit education technology }\end{array}$ & $\begin{array}{l}\text { Sufficient knowledge about PC, } \\
\text { software, electronic educational } \\
\text { resources, their design and use, ways } \\
\text { of network interaction and interactive } \\
\text { communication in the framework of } \\
\text { educational process while credit } \\
\text { education technology }\end{array}$ & $\begin{array}{l}\text { Advanced knowledge about PC, } \\
\text { software, electronic educational } \\
\text { resources, their design and use, ways } \\
\text { of network interaction and interactive } \\
\text { communication in the framework of } \\
\text { educational process while credit } \\
\text { education technology }\end{array}$ \\
\hline Operational & $\begin{array}{l}\text { Minimum skills information } \\
\text { collection, storage and processing } \\
\text { at PC, electronic educational } \\
\text { resources design and use, the use } \\
\text { of network technologies, } \\
\text { interactive communication to } \\
\text { organize educational process } \\
\text { while credit education technology }\end{array}$ & $\begin{array}{l}\text { Sufficient skills information } \\
\text { collection, storage and processing } \\
\text { at PC, electronic educational } \\
\text { resources design and use, the use } \\
\text { of network technologies, interactive } \\
\text { communication to organize } \\
\text { educational process while credit } \\
\text { education technology }\end{array}$ & $\begin{array}{l}\text { Expanded skills information collection, } \\
\text { storage and processing at PC, electronic } \\
\text { educational resources design and use, } \\
\text { the use of network technologies, } \\
\text { interactive communication to organize } \\
\text { educational process while credit } \\
\text { education technology }\end{array}$ \\
\hline
\end{tabular}

Table 2. The results of final diagnosis of control and experimental groups.

\begin{tabular}{cccc}
\hline Level of technological readiness & Teaching stages & Control group, people (\%) & Experimental group, people (\%) \\
\hline$\%-25 \%$ & Basic & $24(30 \%)$ & $0(0 \%)$ \\
$25 \%-50 \%$ & Applied & $46(57 \%)$ & $7(1 \%)$ \\
$50 \%-75 \%$ & Network & $7(9 \%)$ & $4(5 \%)$ \\
$75 \%-100 \%$ & Interactive & $3(4 \%)$ & $82(94 \%)$ \\
\hline
\end{tabular}

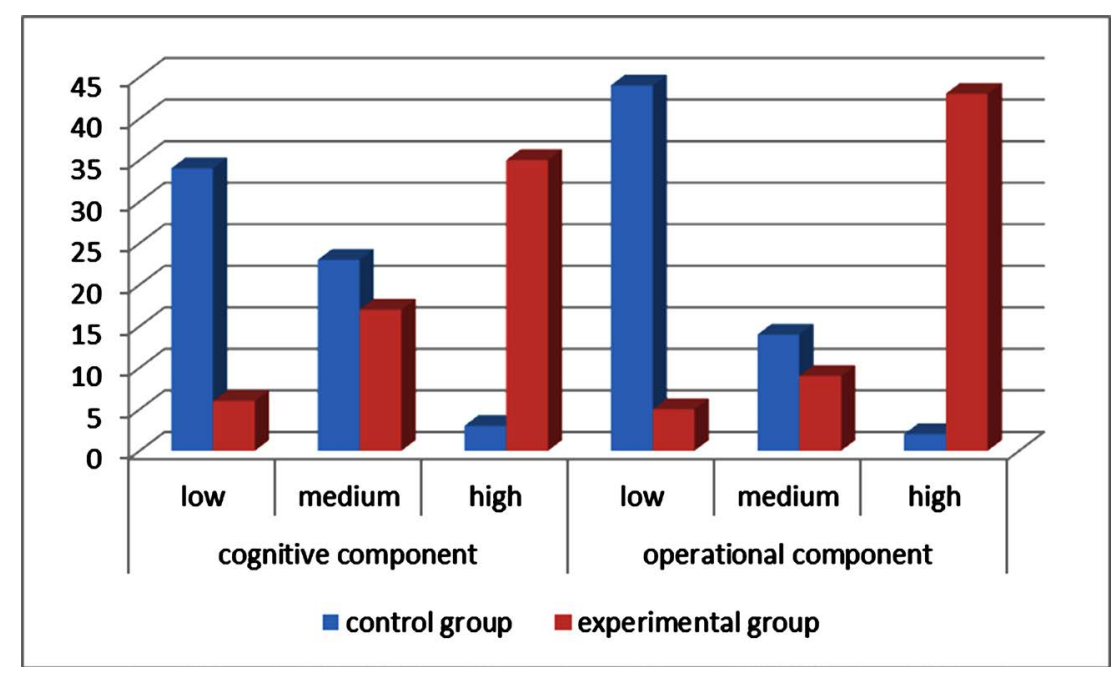

Figure 2. Diagram of the maturity of cognitive and operational components of technological readiness according to the levels, \%. 
Received data was checked for fidelity and adequacy of the results with the use of mathematical statistics: dispersive analysis, the main component of which is Fischer criterion.

Received empirical value $\varphi^{*}$ is within significance zone. $\mathrm{H}_{0}$ is rejected. Consequently it is possible to state with $99 \%$ probability that the number of the testees successfully coping with the course is significantly more in comparison with control group. Research outcomes have shown that many stages model of the formation of university lecturers technological readiness formation to use virtual educational environment while credit educational technology is efficient. It is proved by the outcomes of control and experimental group diagnosis.

\section{Conclusions}

Conclusions, formulated on the basis of research outcomes, allowed offering practical recommendations to form university lecturer's technological readiness in virtual educational environment while credit education technology.

Present research does not cover all the aspects of complicated and many-sided problem of university lecturer's technological readiness formation.

The issues of all social institutes' activity coordination are required. Their purpose is to participate in the formation of university lecturer's technological readiness formation and also the issues of instruments' design of psychological-pedagogical diagnosis of the process of technological readiness formation.

\section{References}

[1] Abdygaparova, S.B., Akhmetova, G.K., Ibatulin, S.P., Kusainov, A.A., Myrzalieyv, B.A., Omirbayev, S.M., Kulekeyev, Z.A., Gamarnik, G.N. and Abdrasilov, B.S. (2004) Course Book-The Fundamentals of Credit Education System in Kazakhstan. Kazakh University, Almaty, 198.

[2] Zavalko, N.A. and Sakhariyeva, S.G. (2013) Modern Educational Technologies. Course Book for Master Students, Ust-Kamenogorsk, 254.

[3] Andreyev, A.A. and Soldatkin, V.I. (1999) Distant Learning, Essense, Technology, Organization. MESI Publishing House, Moscow, 196.

[4] Hutorskoy, A.V. (2000) About Virtual Education. Distant and Virtual Education: Digest of Russian and Foreign Press, 1, 25-27. 